\title{
INNOVATION IN LIBRARY SERVICES POST COVID-19 PANDEMIC
}

\author{
Ludya Arica Bakti ${ }^{1 *}$, Abdurrakhman Prasetyadi ${ }^{2}$, Dwiyanto Wahyu Ari Nugroho ${ }^{3}$, Cahyo \\ Trianggoro $^{4}$, Nur Rizzal Rosiyan ${ }^{5}$, and Hendro Subagyo ${ }^{6}$ \\ ${ }^{123456}$ Center for Scientific Data and Documentation - Indonesian Institute of Sciences \\ Jalan Jendral Gatot Subroto No. 10, Karet Semanggi, Setiabudi, Jakarta
}

*Correspondences: ludya.arica.bakti@lipi.go.id, abdurrakhman.prasetyadi@lipi.go.id, sufizt@.gmail.com, cahyotriangs@gmail.com, nur.rizzal.rosiyan@lipi.go.id, hendro.subagyo@lipi.go.id

\begin{abstract}
Covid-19 pandemic which has hit many parts of the world has changed various living arrangements including documentation, information, and library. Thus, library organizations need to adapt in response to addressing service demands in the new normal era. This study analyzed the use of social networking services in post-COVID19 libraries based on Zoom webinar. The results of the analysis revealed that most participants (97\%) declare the importance of changing the role of libraries and librarians post COVID-19. In addition, participants also felt the importance of innovation (88\%) in creating new products by librarians to meet the needs of post-COVID-19 users. Changing the librarian's paradigm is also needed according to (94\%) participants, by changing the mindset and working patterns of traditional librarians (providing services) into a digital information and literacy creator. The findings of this study are expected to help stakeholders improve services in libraries.
\end{abstract}

Keywords: Library services, Zoom application, library, social media.

\begin{abstract}
ABSTRAK
Pandemi Covid-19 yang melanda berbagai belahan dunia telah merubah berbagai tatanan hidup tidak terkecuali pada bidang dokumentasi, informasi, dan perpustakaan. Maka organisasi perpustakaan perlu menyesuaikan diri untuk menghadapi kebutuhan layanan di era new normal. Kajian ini menganalisis penggunaan layanan jejaring sosial di perpustakaan pasca COVID-19 berbasis Zoom webinar. Hasil analisis mengungkapkan bahwa sebagian besar partisipan (97\%) merasa pentingnya perubahan peran perpustakaan dan pustakawan pasca COVID-19. Selain itu, partisipan juga merasa pentingnya inovasi (88\%) dalam menciptakan produk baru oleh pustakawan guna memenuhi kebutuhan pengguna pasca COVID-19. Mengubah paradigma pustakawan juga dibutuhkan menurut (94\%) partisipan, dengan mengubah pola pola pikir dan cara kerja pustakawan yang tradisional (melayani) menjadi seorang kreator informasi dan literasi digital. Temuan kajian ini diharapkan dapat membantu para pemangku kepentingan untuk meningkatkan layanan di perpustakaan.
\end{abstract}

Kata kunci: Layanan perpustakaan, aplikasi Zoom, perpustakaan, media sosial.

\section{INTRODUCTION}

The disease caused by Coronavirus, which is later known as COVID-19, spreads from person to person in the same mechanism as the flu virus. The infection expands through a droplet of sufferers when coughs or sneezes to an uninfected person through the eyes, nose, or mouth. Feces-oral viral transmission is not yet confirmed in the COVID-19 contagiousness, but patients undergo severe acute respiratory syndrome (Heymann and Shindo 2020). Since the COVID-19 pandemic quickly spread to countries around the world (Lipsitch, Swerdlow and Finelli 2020), Indonesia is one of those countries that are affected by the COVID-19 pandemic. On Monday (2/3/2020), the Indonesian Ministry of Health announced Indonesia's COVID-19 first case of two people living in Depok, West Java (Ihsanuddin 2020). Thus, the outbreak has made many aspects of our social lives were being altered ever since.

Assuring public health awareness along with serving the most recent information to the community should become the library's commitment as a social institution. Various sources of information and communication channels that available recently, are not guaranteeing users to always access accurate 
information. On the other hand, libraries are prosecuted to reach loyal users and communities by serving accessible services online. As a consequence, librarians are also asked to adapt and improve their skills.

Popularly seen as electronic versions of public libraries, digital libraries offer more advantages for users including no physical boundary and unlimited access of 24 hours to the information since collections are stored in digital form. Furthermore, as a combination of technology and information resource, a digital library allows remote access to minimize physical and time barriers. In the current era of information explosion, librarians need to renew their skills in searching, repackaging, and guiding users to obtain appropriate information. In order to organize extensive and varied information, librarians are required to have skills in accordance with the development of existing information technology.

Appropriate skills enable librarians to obtain accurate and valid information sources in different types and forms available on the internet. Those up-skilled librarians will be beneficial for users because customers will find them helpful in finding faster and specific information that is needed. During a pandemic, libraries must also continue to maintain their regular patrons. Due to recent large-scale social restrictions applied, many libraries in Indonesia have provided virtual support to their users, such as providing references, sending documents, literature searching, and systematic reviews. Some libraries have started webinars and online sessions to interact with users through Google Classroom, Google Hangouts, Skype, or Zoom.

Most libraries are temporarily closed due to the COVID-19 pandemic. Some libraries combine users' needs that originally come to the library as public space then switched to digital services. The use of Zoom video as a communication platform has been in massive use in recent months. People are looking for ways to do work from home or connect with their loved ones in the absence of physical contact. In addition, some libraries offer meetings through Zoom as a means of communication. This study was conducted to determine participants' opinions about (1) library and librarian role post-COVID-19, (2) library's innovative data service products, and (3) the existence of librarians for both during and postpandemic.

\section{METHOD}

A survey method was used for data collection. At the time of the survey, information was collected from respondents using a questionnaire as an instrument for collecting data, was distributed through online media. Samples were taken from participants who attended a webinar titled "Perpustakaan dan Pustakawan Menghadapi New Normal”.

\section{RESULTS AND DISCUSSIONS \\ Social networking services}

Social networking service is a new growing trend to receive and information sharing channel (Steiner 2012), librarians need to be familiar with various types of social networking services and use them to promote library collections and services (Solomon 2013). For example, the Indonesian Institute of Sciences through the Center for Scientific Data and Documentation (PDDI) has provided its social networking services on Facebook, YouTube, and Twitter to provide relevant information about research and library activities. Although it is easy to create accounts on social networking services, librarians or library administrators must emphasize the importance of building connections with users to maximize the value of their social networking services (Harrison, et al. 2017). 
Social media can be considered as an online platform that allows individuals to connect, communicate, collaborate, and share content (Boyd and Ellison 2007). One important example is Facebook, which was launched in 2004 and has 2.6 monthly billion active users by March 31, 2020 (Noyes 2020). Being popular, social media activity has been adopted in many different contexts, including education (Au and Wei 2014), social media marketing (Lui and Au 2017), and community involvement (Au and Ho, Deliberation in mobile messaging application: A case in Hong Kong 2019). More specifically, in the context of libraries, librarians, and administrators, social media-networking services support is beneficial in terms of cost-effectiveness, efficiency for disseminating news, promoting services, and maintain communication with their users (Chu and Du 2012). Table 1 shows the use of several social networking services in the library.

Table 1. Application social networking services in library

\begin{tabular}{|l|l|}
\hline Social Media & Application in library \\
\hline Facebook & $\begin{array}{l}\text { Tomaiuolo (2012) suggests libraries can create Facebook pages to communicate with } \\
\text { their users and pass on resources in the library. Libraries can also adopt chatbots to } \\
\text { offer users automatic answers to some common questions or links to different } \\
\text { catalogs and online databases (Harrison, et al. 2017). }\end{array}$ \\
\hline YouTube & $\begin{array}{l}\text { As a video sharing service with social features, YouTube allows librarians to set up } \\
\text { channels for library users to subscribe to or just by viewing. YouTube's main strength } \\
\text { is creating a community for users to interact, comment, and view/post videos with } \\
\text { specific interests. As such, this allows libraries to reach their users with videos } \\
\text { (Landis 2010). Among various types of videos, Tomaiuolo (2012) identified that the } \\
\text { most popular types of videos uploaded by libraries are usually related to user } \\
\text { education, such as tutorials searching through Google Scholar. }\end{array}$ \\
\hline Twitter & $\begin{array}{l}\text { Created in 2006, Twitter had 330 million active users in 2019 (Statistia 2019). In the } \\
\text { context of the library, Twitter can be used to broadcast information, and thus build } \\
\text { stronger bonds with users (Bradley 2015) (Young 2017). }\end{array}$ \\
\hline
\end{tabular}

Source: (Fong, et al. 2020)

As illustrated in Table 1, the main purpose of libraries in using social networking services is to build bonding with their users, encourage more users to utilize their services, and participate in various events. In addition, the library also expects a well established-credibility of their own. Working on user's persuasion to get them well engaged and building networks, in essence, can be counted as creating social evidence and the library's social assets.

\section{Zoom application}

Zoom Video Communications (San Jose, CA) was originally founded in 2011 by Eric Yuan, an engineer from Cisco Systems (San Jose, CA), and was launched in 2013 under the name Saasbee. Zoom offers organizations and individuals a faster way to communicate relatively using audio-only, chat, and email meetings, and it is not restricted by geography, so employees have more flexibility to work from home (Weiner 2017). The number of individuals who use Zoom Meetings, Zoom's main video communication product, has now reached 40 million, with 65,000 organizations subscribed. In early 2020, Zoom usage increased $67 \%$ during the first 3 months of the year due to the coronavirus pandemic. Many organizations implement work from home policies and divert meetings and services to Zoom Meetings. The Zoom application has been downloaded 343,000 times in 1 day, and about $18 \%$ of downloads were from the United States. Zoom helps over 300 million daily meetings, thus participants easily stay connected during the COVID-19 pandemic (Warren 2020). 
Zoom webinar able to hold as many as 400 people, we explained information about guidance, participation, and registration in Figures 1, 2, and 3. Both Zoom meetings and Zoom webinars provide polling features. This section aimed to analyze whether participants can understand the guidelines, number of participations, and registration methods provided by the committee.

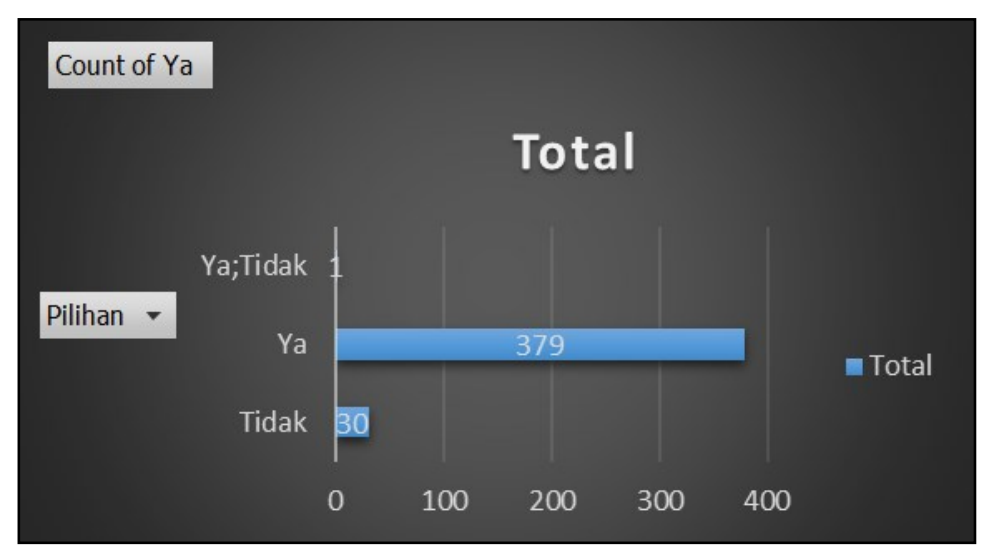

Figure 1. Guidelines

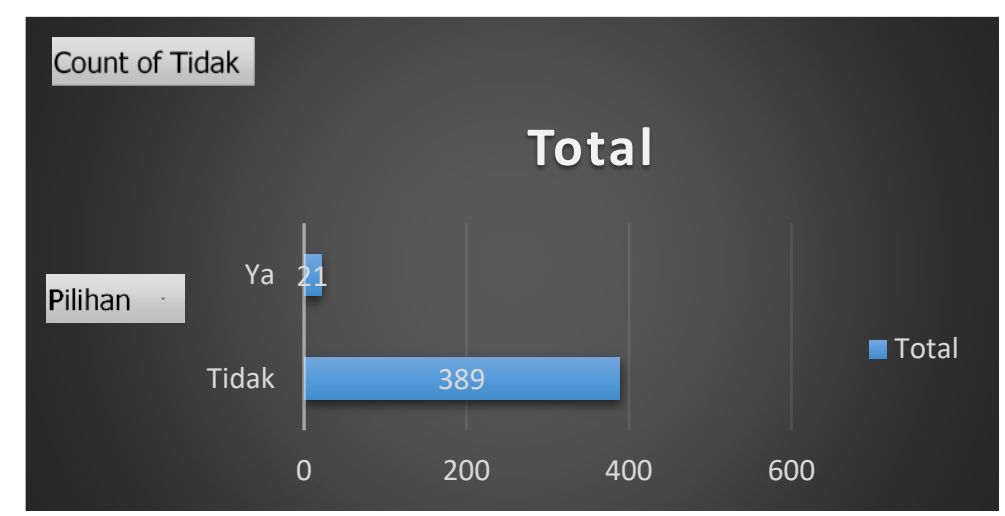

Figure 2. Participation

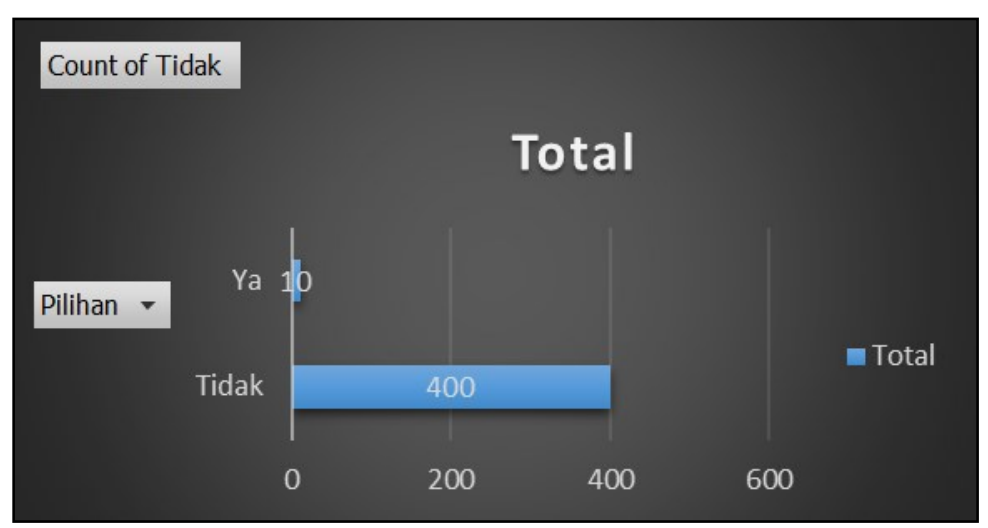

Figure 3. Registration

As shown in Figure 1, as many as $92.43 \%$ of people read the webinar guidelines provided, while the remaining $7.57 \%$ did not. Furthermore, $94.87 \%$ of people stated that they could participate in the webinar, while other $5.12 \%$ claimed to have difficulties when trying to enter the Zoom webinar application (Figure 2). Figure 3 shows that $97.56 \%$ of people stated that they could participate in the registration process, while $2.43 \%$ admitted difficulties. 


\section{Library and librarian roles}

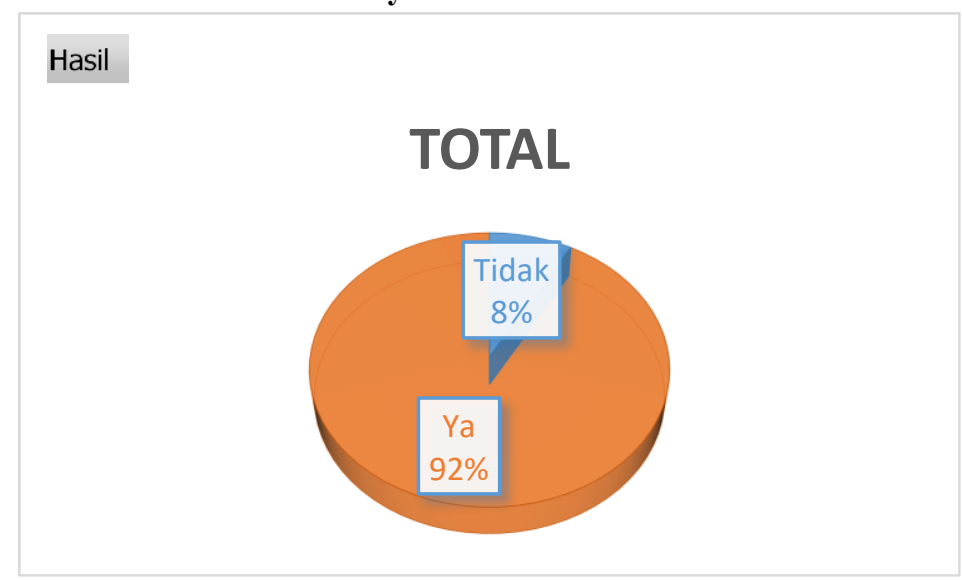

Figure 4. Library services

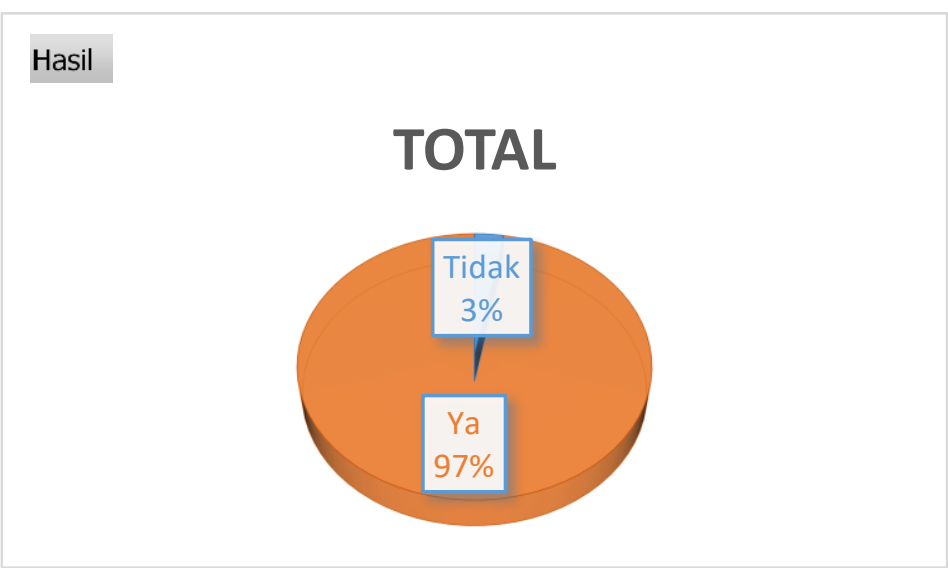

Figure 5. Changes of librarian and library roles.

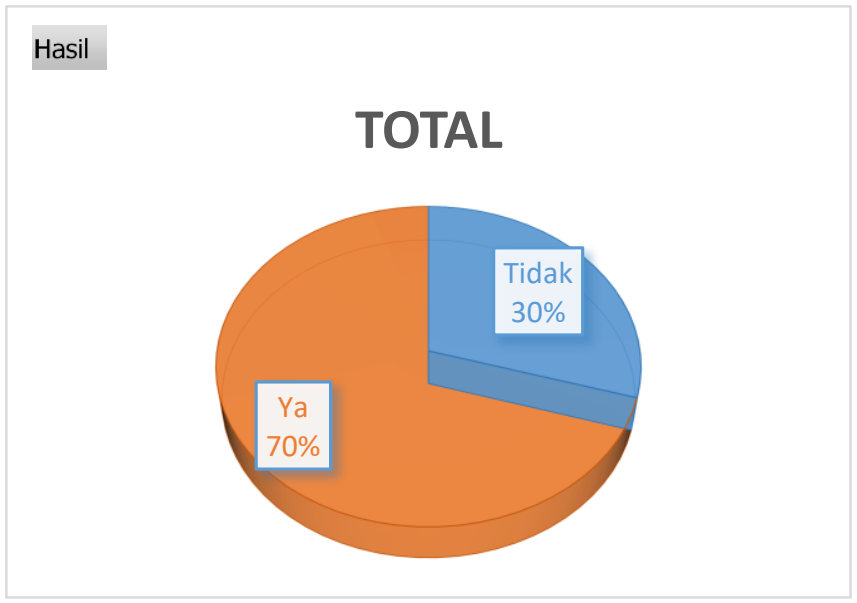

Figure 6. Research data service management

Polling results show that in the first session, $92 \%$ of people able to figure out the types of new services for the industrial era library 4.0, and another $8 \%$ did not understand what types of services could be provided in their libraries (Figure 4). Figure 5 presents fact that $97 \%$ of webinar attendance understood the changing role of libraries and librarians in the 4.0 era, while $3 \%$ did not. Based on Figure 6, it can be observed that as many as $70 \%$ of people capable of managing research data services in the industrial 
era library 4.0 , while $30 \%$ did not yet learn how to manage research data services in libraries.

\section{Library data service innovation products}

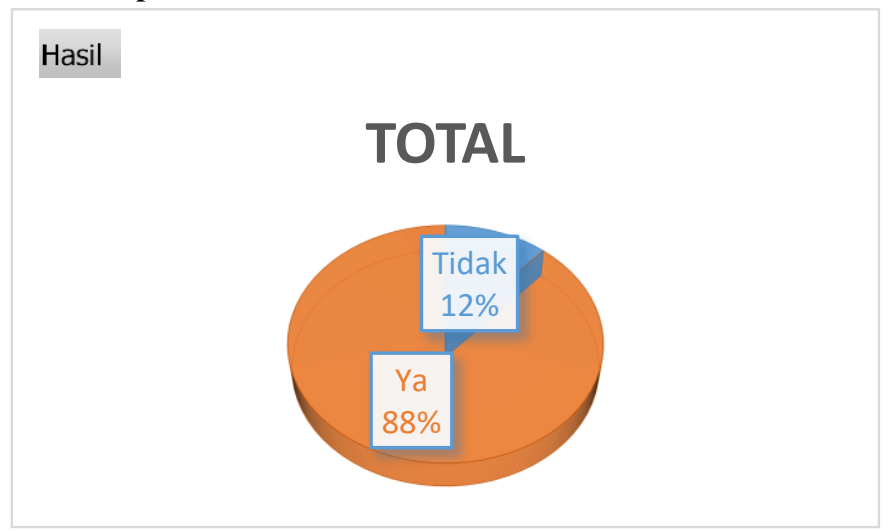

Figure 7. Development of innovation products

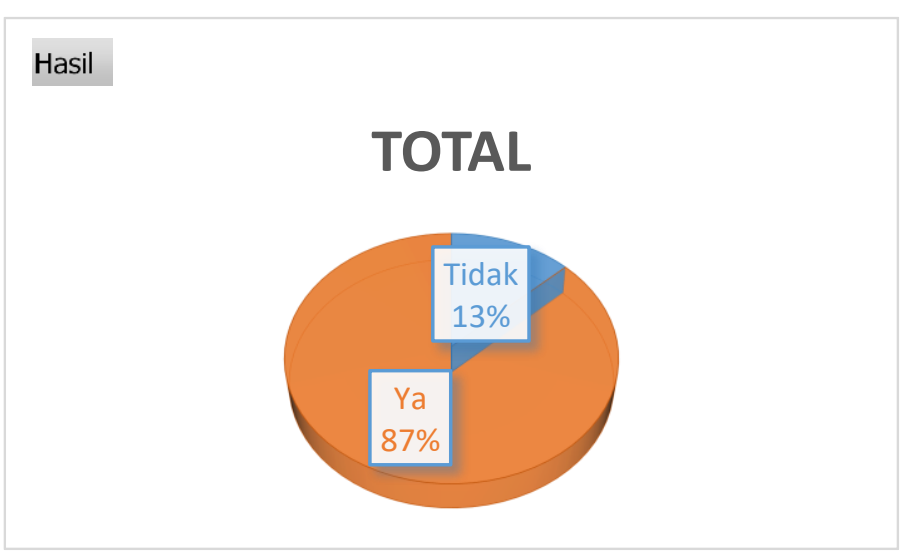

Figure 8. Targets of innovation products

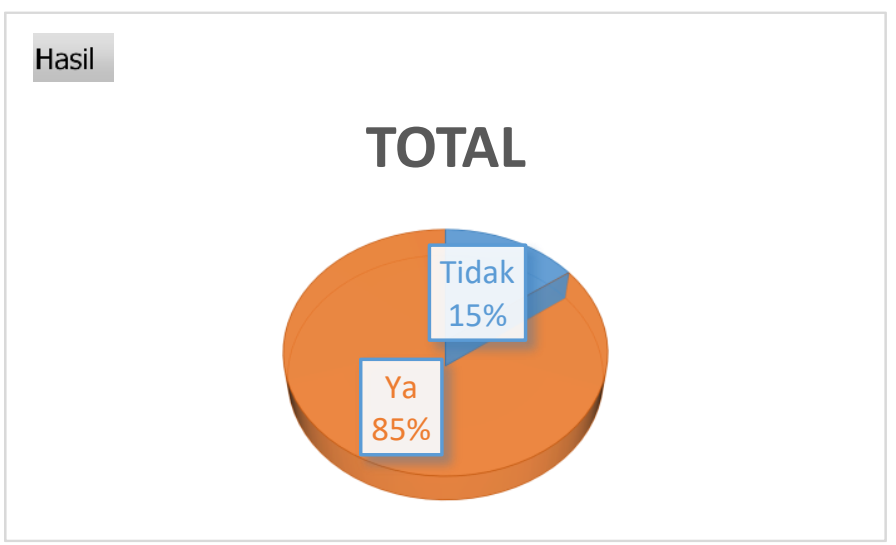

Figure 9. Digital sources management.

During the second session of material explanation, it was noted that $88 \%$ of people recognized innovative products that have the potential to be developed after COVID-19, while the remaining 12\% did not know about innovative products possibly created by libraries or served agencies (Figure 7). Figure 8 describes $87 \%$ of people can specified target of innovation product to be achieved post-COVID19 and the other $13 \%$ have not set a target. Furthermore, Figure 9 tells that as many as $15 \%$ of people unaware of digital sources that can be processed into products post COVID-19, while the other $85 \%$ 
knowledgeable that digital sources can be processed into knowledge products for libraries and agencies that are served.

\section{Librarian Existence}

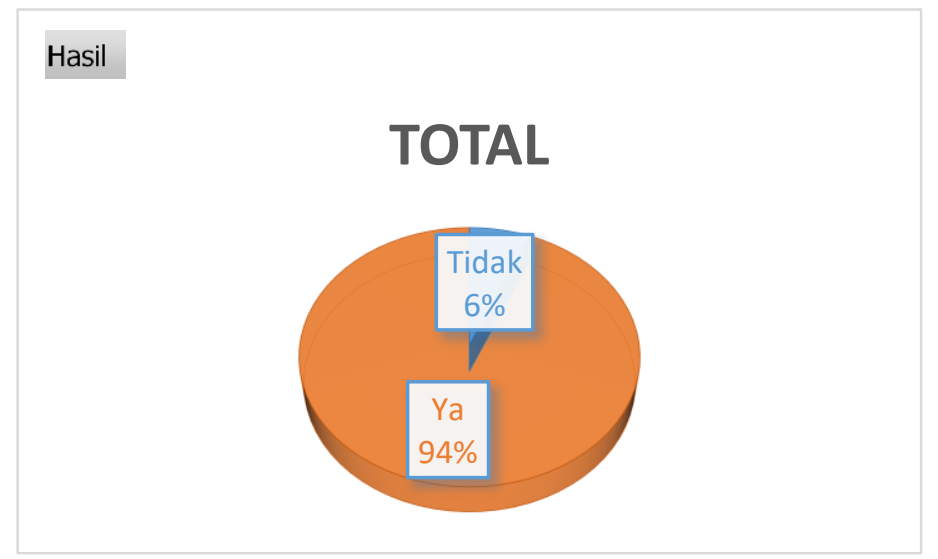

Figure 10. Paradigm of librarian's post COVID-19

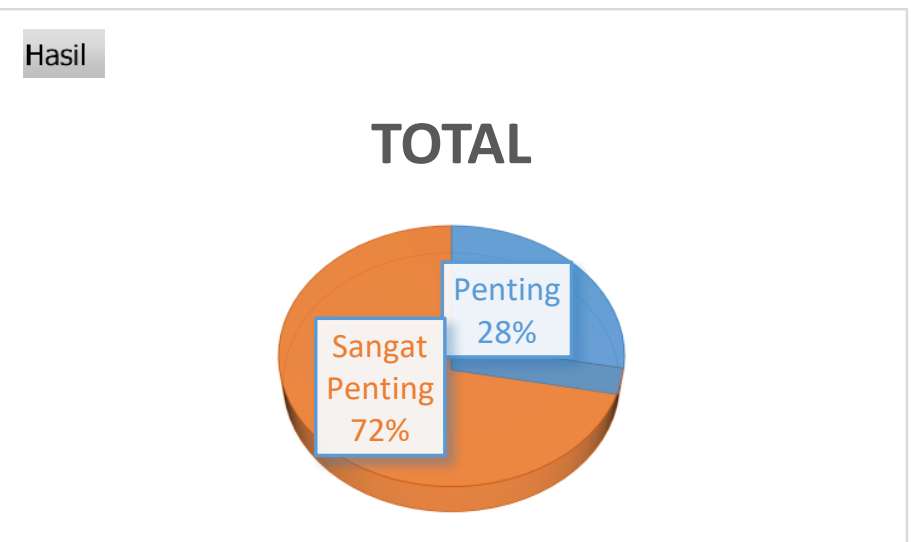

Figure 11. The importance of changing the librarian paradigm post COVID-19

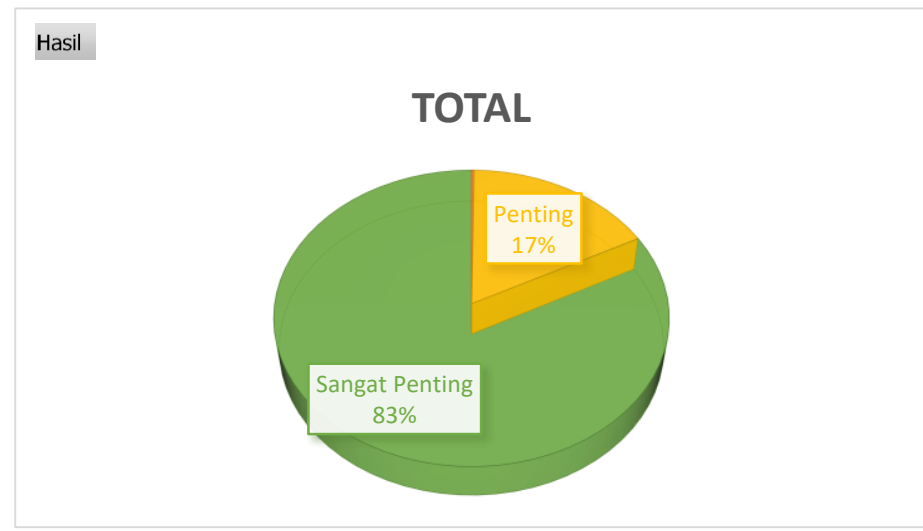

Figure 12. Information literacy skills

Finally, during the last material explanation, $94 \%$ of people understood how to change the paradigm of librarian's post-COVID-19, while the remaining $6 \%$ did not feel the need to change the paradigm (Figure 10). Figure 11 confirms $72 \%$ of people stated that it is important to change the paradigm of librarians post- COVID-19 and another $28 \%$ have not felt the need to change the paradigm of librarians. Furthermore, in Figure 12, it can be seen that $83 \%$ of people are aware that information literacy skills are needed especially for librarians' post COVID-19, while the other $17 \%$ are not. 


\section{CONCLUSIONS}

Librarians and administrators of social networking services must begin to understand user needs through regular surveys and discussions, bearing in mind that applied library services will always be dynamic following the use of social networking applications that are constantly changing. It is important for libraries to understand user preferences on social media content and other needs, by doing so, librarian and administrator can provide more accurate and up-to-date information to users, and thereby increase the presence and involvement of library and librarian in the community. For example, during and post COVID-19 pandemic, the library can update information about research data, provide services and other resources that can be accessed by users from home. In addition, librarians can set simple and measurable goals for participation and library services performance post-COVID-19 pandemic, with various social media measurement models, which include conversation, sharing, and reference features provided by various applications. Before the first industrial revolution, new technological and material discoveries were mostly spontaneous creation. However, after the emergence of mass production, product and user relations have become increasingly close, user-centered thinking has been applied in the management area. Providing users with a new experience has become one of the library services missions during the COVID-19 pandemic. Library innovation is driven by advances in information and communication technologies. For the purpose of achieving excellent performance, libraries must focus on information needed by users as well as maintain close relationships with users. Moreover, innovation can encourage scientific research instead. Meanwhile, librarians not only need to improve their skills in mastering new technologies and information but also capable to promote their services and products.

Adoption of rapidly developing information technologies, librarians as information workers are required to have the ability to access and identify which sources are valid, reliable, and accurate. Social media platforms provide a variety of features and capabilities that are tailored to users' needs, offering librarians the opportunity to create interactive and creative information products. Changes in the paradigm of librarians are developed by mastering the skills of information and communication technology. Technology proficiency skills will be an advantage for librarians in carrying out library functions as a medium of information, education, recreation, and other related supports. Libraries should offer aid for digital literacy workshops and training. Librarians and administrators of social networking services can follow the pages of other institutions that can help them stay abreast of trends and learn new technical skills from others. In addition, as social media develops and changes rapidly, libraries need to set their service policies in management to achieve their goals (Vassilakaki and Garoufallou 2015). Quality management ensures library performance, product and service are consistent. The findings of this study are expected to help stakeholders improve library service and further research on the issue might require in-depth analysis.

\section{BIBLIOGRAPHY}

Au, Cheuk Hang, and H.E. Wei. 2014. "Using WiKi for project collaboration-with comparison on Facebook." Lecture Notes in Engineering and Computer Science 358-363.

Au, Cheuk Hang, and Kevin K. W. Ho. 2019. "Deliberation in mobile messaging application: A case in Hong Kong." Communications of the Association for Information Systems 45: 270-298. doi:10.17705/1CAIS.04517.

Boyd, Danah M., and Nicole B. Ellison. 2007. "Social network sites: Definition, history, and scholarship." Journal of Computer-Mediated Communication 13 (1): 210-230.

Bradley, Phil. 2015. Social media for creative libraries. Facet Publishing.

Chu, Samuel Kai-Wah, and Helen S Du. 2012. "Social networking tools for academic libraries." Journal of Librarianship and Information Science 45 (1): 64-75. 
Fong, Kenny Cheuk Hei, Cheuk Hang Au, Ernest Tak Hei Lam, and Dickson K.W. Chiu. 2020. "Social network services for academic libraries: A study based on social capital and social proof." The Journal of Academic Librarianship 46 (1): 1-6.

Harrison, Amanda, Rene Burress, Sarah Velasquez, and Lynnette Schreiner. 2017. "Social media use in academic libraries: A phenomenological study." The Journal of Academic Librarianship 43 (3): 248 256.

Heymann, David L, and Nahoko Shindo. 2020. "COVID-19: what is next for public health?" The Lancet 395: 542-545. doi:10.1016/S0140-6736(20)30374-3.

Ihsanuddin. 2020. Fakta Lengkap Kasus Pertama Virus Corona di Indonesia. Jakarta: Kompas, Maret 3. Accessed 2020. https://nasional.kompas.com/read/2020/03/03/06314981/fakta-lengkap-kasus-pertamavirus-corona-di-indonesia?page=all.

Khan, Shakeel Ahmad, and Rubina Bhatti. 2012. "Application of social media in marketing of library and information services: A case study from Pakistan." Webology 9 (1): 1-8.

Landis, Cliff. 2010. A social networking primer for librarians. New York: Neal-Schuman Publishers.

Lipsitch, Marc, David L. Swerdlow, and Lyn Finelli. 2020. "Defining the epidemiology of Covid-19—studies needed." New England Journal of Medicine 382: 1194-1196. doi:10.1056/NEJMp2002125.

Lui, Richard W.C., and Cheuk Hang Au. 2017. "Designing simulation games for information systems education - A case study in teaching for digital marketing." 2017 IEEE 6th International Conference on Teaching, Assessment, and Learning for Engineering (TALE). Hong Kong: IEEE. 290-295. doi:10.1109/TALE.2017.8252349.

Noyes, Dan. 2020. The Top 20 Valuable Facebook Statistics - Updated June 2020. June 22. Accessed July 3 , 2020. https://zephoria.com/top-15-valuable-facebook-statistics/.

Rosenberg, Joshua Michael, Colin A. Terry, John Bell, and Virginia Hiltz \& Tracy E. Russo. 2016. "Design guidelines for graduate program social media use." TechTrends 60 (2): 167-175. doi:10.1007/s11528016-0023-x.

Solomon, Laura. 2013. The librarian's nitty-gritty guide to social media. Chicago: American Library Association.

Statistia. 2019. "Number of monthly active Twitter users worldwide from 1st quarter 2010 to 1 st quarter 2019 (in millions)." Statista. Accessed Maret 27, 2020. https:/www.statista.com/statistics/282087/number-ofmonthly-active-twitter-users/.

Steiner, Sarah K. 2012. Strategic planning for social media in libraries. Vol. 15. American Library Association.

Tomaiuolo, Nicholas G. 2012. UContent: The information professional's guide to user-generated content. Information today, incorporated.

Vassilakaki, Evgenia, and Emmanouel Garoufallou. 2015. "Library Facebook practices for creating and promoting a professional profile." Program 49 (3): 343-359. doi:10.1108/ PROG-10-2014-0073.

Warren, Tom. 2020. "Zoom admits it doesn't have 300 million users, corrects misleading claims." April 30. https://www.theverge.com/2020/4/30/21242421/zoom-300-million-users-incorrect-meetingparticipants-statement.

Weiner, Yitzi. 2017. "The Inspiring Backstory of Eric S. Yuan, Founder and CEO of Zoom." Medium. October 3. Accessed June 27, 2020. https://medium.com/thrive-global/the-inspiring-backstory-of-eric-s-yuanfounder-and-ceo-of-zoom-98b7fab8cacc.

Young, Jimmy A. 2017. "Facebook, Twitter, and blogs: The adoption and utilization of social media in nonprofit human service organizations." Human Service Organizations: Management, Leadership \& Governance 41 (1): 44-57. doi:10.1080/23303131.2016.1192574. 